\title{
일본 해외긴급재난 구호 시스템
}

\section{1. 일본 정부내 업무 조정}

매외 긴급원조 관련 일본 정부내 업무는 '국제긴 급원조대의 파견에 관한 법률' 에 의거 외무성에 서 총괄

- 동 관련 외무성 국제긴급원조실은 관계성청간 의 업무연락, 파견인원 확정 등의 업무를 담당 하고, 실제 operation은 JICA의 긴급원조대 사 무국(직원 : 15 명)에서 실시

ㅁ외무성은 피해국 또는 국제기관으로부터 긴급원 조 요청이 있는 경우 내용에 따라 관계 정부기관 및 국가공안위원장과 협의할 수 있음.

- 연호 법률은 관계기관을 내각부, 경찰청, 방위청, 총무성, 소방청, 문부과학성, 후생노동성, 농림수 산성, 경제산업성, 자원에너지청, 국토교통성, 해 상보안청, 기상청, 환경성 등 14 개 기관으로 적시 ㅁ 실제 긴급구호대는 외무성 및 JICA가 주로 경찰 청, 소방청, 해상보안청 등과 협의하여 파견인원 등 결정
- 실무적으로 파견인원 및 구성 등은 외무성 국제 긴급원조실 실장(과장) 수준에서 결정(신속한 대 응 필요에 따라)

\section{2. 긴급구호대 편성 및 파견}

ㅁ국제긴급구호대는 구조팀, 의료팀, 전문가팀 및 필요시 자위대 파견으로 나뉘어짐.

- 피해발생시 최단기간내 구조팀을 먼저 파견하 고, 이후 의료팀, 전문가팀(필요시)을 순차적으 로 파견

\section{가. 구조팀}

ㅁ 직접적인 인명구조 등을 담당하는 구조팀의 경우 피해 발생 후 72 시간이 경과하면 생존자 구출의 가 능성이 적어지므로 3 일 이내 파견을 원칙으로 함. - 파키스탄 지진의 경우 피해 발생 다음날 아침 출발 ㅁ 통상 20 100명을 파견(파키스탄 지진의 경우 49 명 파견) 
ㅁ 동 요원은 외무성(단장) 및 JICA 인원(업무조정)과 더불어 경찰청, 소방청, 해상보안청 등 3 개청의 직 원중 사전에 등록된 인원에서 확보함.

- 현재 소방기관 600 여명, 경찰 450 여명, 해안보 안청 350 여명 등 총 약 1,400 명 확보

- 동 인원에 대해서는 JICA에서 연 2, 3회 연수를 실시

해외재난 발생시 외무성 국제긴급원조실에서 경 찰청 등 3 개청에 필요인원 등을 연락하게 되며, 3 개청이 이에 응하여 인원을 구성

\section{나. 의료팀}

ㅁ의료팀의 경우에도 외무성(단장) 및 $\mathrm{JCA}$ (업무조 정) 인원과 더불어, 실제 의사, 간호사, 약제사 등 은 JICA에 사전 등록된 인원에서 선발(통상 10 20명 정도 파견)

- 현재 의사 209 명, 간호사 287 명, 약제사 25 명이 $\mathrm{JICA}$ 에 등록되어 있으며, JICA에서 정기적으 로 연수를 실시

해외재난 발생시 사전등록된 의사 등에 대하여 일 제히 팩스 등으로 모집, 인원을 구성함.

ㅁ의료팀도 피해발생 직후 가급적 이른 시기에 파견 되며, 대개 2 주정도 활동함(필요할 경우 2 차 의료 팀도 파견).

\section{다. 전문가팀}

ㅁ 전문가팀은 재해확대 방지를 위한 전문적 조언 등 을 행하기 위한 목적으로 파견되는 바, 상기 14 개 관계 정부기관의 전문가를 파견(3 10명)하며, 사
전에 등록된 인원은 없음.

\section{라. 자위대 파견}

ㅁ해외재난 발생시 특별한 경우에 자위대를 파견하 는 경우도 있으며, 이때에도 외무성이 중심이 되 어 파견여부를 검토함.

\section{3. 긴급 물적원조}

ㅁ 상기와 같은 인적원조 뿐 아니라 텐트, 모포 등 긴 급한 물적원조를 위한 태세도 구비중

JICA가 런던, 마이애미, 싱가폴 등 3군데에 긴급 원조물자 비축창고를 운영하고 있으며, 사태 발생 시 가장 가까운 비축창고에서 물자를 지원

- 실제 비축창고는 일본통운 등 일반 물류회사의 창고를 빌려서 운영하고 있는 바, 관리 등은 동 회사에서 담당

\section{4. 예산 확보 및 민간인 보상 등}

ㅁ 상기와 같은 긴급 인적, 물적지원을 위한 예산은 $\mathrm{JICA}$ 교부금중 '재해원조협력비' 로 확보 - 동 규모는 매해 변동이 심하나, 최근에는 6 억엔 정도

- 실제 운영과정에서 동 예산이 부족한 경우가 많은 바, 이 때에는 추가편성 예산 또는 예비비 사용

만편, 긴급 자금원조의 경우에는 외무성 예산으로 편성된 '재해관계원조비'에서 지출하며, 일반적인 무상원조와 마찬가지로 무상원조 협력과에서 판 단, 집행

ㅁ 긴급원조대에 참여하는 의사 등 민간인에 대해서 
는 사고 등 발생시 공무원과 대등한 보상이 이루어지 도록 제도가 마련되어 있으며, 민간인의 참여로 인한 회사(병원)의 손해는 JICA에서 소속 회사(병원)에 보 전해 줌.

\section{NGO 등과의 협력}

ㅁ NGO 등 긴급원조에 별도로 참여하는 민간단체에 대한 지원 등 사례는 없음.

[자료:주일본 대사관] 